\title{
高速液体クロマトグラフィーによる血清中ヨヒンビンの定量
}

千葉良子, * 石井耀子

昭和薬科大学

\section{Determination of Yohimbine in Serum by High Performance \\ Liquid Chromatography}

\author{
Ryoko CHIBA* and Yoko IsII \\ Showa College of Pharmaceutical Sciences, 1-8, Tsurumaki 5-chome, \\ Setagaya-ku, Tokyo 154, Japan
}

(Received October 19, 1989)

An automated method for determination of yohimbine (Yoh) in the serum was developed by means of column switching high performance liquid chromatography (HPLC).

TSK-precolumn BSA-ODS and TSK-gel ODS-120T were used as a precolumn and analytical column, respectively.

The wavelengths of detection were used at $280 \mathrm{~nm}$ (excitation) and $360 \mathrm{~nm}$ (emission).

A $100 \mu \mathrm{l}$ serum sample is directly injected onto the precolumn.

Yoh is then eluted within $30 \mathrm{~min}$ with an methanol-potassium phosphate buffer mixture.

The analytical recoveries $(99.3-110.4 \%)$, reproducibilities (within-run, C.V. $<2.27 \%$ ), and detection limit $(0.80 \mathrm{ng} / \mathrm{ml}, \mathrm{S} / \mathrm{N}=3)$ indicate that this system is suited for determination of Yoh.

The five healthy volunteers received a single oral dose $10 \mathrm{mg}$ of HYoh powder. The average of the maximal serum concentration and the area under the curve $(A U C)$ from 0 to $4 \mathrm{~h}$ were $10.3 \pm 0.88 \mathrm{ng} / \mathrm{ml}$ and $19.70 \pm 0.87 \mathrm{ng} \cdot \mathrm{h} \cdot \mathrm{ml}^{-1}$, respectively.

The elimination rate constant $\left(K_{\mathrm{el}}\right)$ was $0.52 \pm 0.03 \mathrm{~h}$, and biological half-life $\left(t_{1 / 2 \mathrm{el}}\right)$ was $1.32 \pm 0.12 \mathrm{~h}$.

Keywords-yohimbine; serum; column switching HPLC; fiuorometric detection; pharmacokinetics

緒 言

ヨヒンビン (Yoh) は, 塩酸塩 (HYoh) の形で単独あるいは硝酸ストリキニーネやメチルテストステロンと組 み合せられた製㨈として，インポテンツの治療に用いられている. ${ }^{1-5)}$ その臨休的効果と投与量との関係は明確 にされていない。最近，高速液体クロマトグラフィー（HPLC）の応用による Yoh の分析法が報告されてい る、 ${ }^{6-11)}$ その薬動力学的データの不足は，迅速かつ高感度な測定方法がなかったことがあげられる。著者らは前 報 ${ }^{10)}$ に扔いて，製剤中の HYoh の分析法を発表したが今回は血清中の Yohのよらに，低濃度の動態を求めるの に，前処理つき HPLC 蛍光法 ${ }^{12)}$ がすぐれた方法と考えたので本実験を行った.

\section{実 験 $の$ 部}

1. 試薬及び標準溶液 HYoh 及び内部標準物質として用いたパラヒドロキシ安息香酸メチル (PMBA) は, 東京化成工業製を用いた。メタノール，蒸留水は蛍光分析用（ドータイトルミナゾール，同仁化学研究所製）を， 他の試薬類はすべて特級品を使用した。標準溶液は HYoh 及び PMBA の各々をメタノール-0.1 M リン酸一カ リウム混液 $(40: 60, \mathrm{v} / \mathrm{v})$ で溶解後, $0.05 \mathrm{M}$ リン酸塩緩衝液 $(\mathrm{pH} 7.0)$ で希釈し Yoh 標準溶液 $(10,20,30,40$, $50,60 \mathrm{ng} / \mathrm{ml})$ 及び PMBA 標準溶液 $(3,6 \mu \mathrm{g} / \mathrm{ml})$ とした.

2. HPLC 装置及び分析条件装置は東ソーのPT-8000 自動カラムスイッチング HPLCに蛍光光度計 FS- 
TABle I. Time Program

\begin{tabular}{|c|c|c|}
\hline Time $(\min )$ & Sample preparation column & Analytical column \\
\hline 0 & $\begin{array}{l}\text { Injection } \\
\text { Deproteinization }\end{array}$ & \\
\hline 8.0 & & $\begin{array}{l}\text { The enriched Yoh in the precolumn } \\
\text { are introduced automatically to the } \\
\text { analytical column using the column } \\
\text { switching device. } \\
\text { Separation } \\
\text { Detection }\end{array}$ \\
\hline 30.0 & Stop & \\
\hline
\end{tabular}

8000 を組み合せた。前処理カラム: TSK-precolumn-BSA-ODS-120T (粒子径 $5 \mu \mathrm{m}, 35 \times 4.6 \mathrm{~mm}$ i.d.), 分析カ

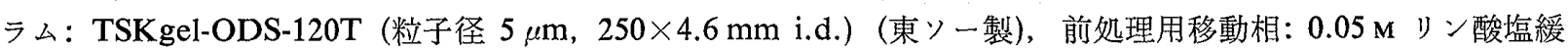
衝液 ( $\mathrm{pH} 7.0$ ), 分析用移動相: メタノール $-0.1 \mathrm{M}$ リン酸一カリウム混液 $(40: 60, \mathrm{v} / \mathrm{v})$, 流速: $0.8 \mathrm{ml} / \mathrm{min}$, 温度: 室温, 蛍光検出: 励起 $(\mathrm{Ex}) 280 \mathrm{~nm}$, 蛍光 $(\mathrm{Em}) 360 \mathrm{~nm}$, 自動カラムスイッチング HPLCのタイムプログラム (Table I).

3. 定量法 PMBA 標準溶液 $(3 \mu \mathrm{g} / \mathrm{ml}) 1 \mathrm{ml}$ を搵清試料 $1 \mathrm{ml}$ 火加光：ミキサーで 10 秒間混和後その 100 $\mu 1$ を前処理カラムを通して HPLC に注入した。血清中の Yoh は PMBA とのピーク面積比より算出した.

4. 検量線の作成 Yoh 標準溶液 $(10,20,30,40,50,60 \mathrm{ng} / \mathrm{ml})$ の各々の溶液 $1 \mathrm{ml}$ に PMBA 標準溶液 $(6 \mu \mathrm{g} / \mathrm{ml}) 1 \mathrm{ml}$ ずつを加えてょく混和した.さらに，この溶液 $1 \mathrm{ml}$ にブランク血清 $1 \mathrm{ml}$ を加え前述の定量法に 従い濃度測定し検量線を作成した。

5. 添加回収実験 ブランク血清（及び 0.05 M リン酸塩緩衝液 $\mathrm{pH} 7.0$ ) $1 \mathrm{ml}$ K Yoh $2.5,5.0$ 及び $10 \mathrm{ng}$ と PMBA $1.5 \mu \mathrm{g}$ を添加し，3 の操作に従い測定し回収率を検討した.

6. 血清試料の調製 本大学のボランティア学生 (健常男子, 年齢 19-24 歳, 体重 56-70 kg) 5 名に前夜 より 12 時間絶食後午前 10 時に HYoh $10 \mathrm{mg}$ を水とともに投与した。採血は投与前，投与後 15,30 分，1，2， 4 時間後に行った. 採血量は, 1 回あたり約 $5 \mathrm{ml} て ゙$ 血液は $3000 \mathrm{rpm}$ で 15 分間遠心後, 血清を分離し測定ま で $-20^{\circ} \mathrm{C}$ にて凍結保存した，測定前に $4^{\circ} \mathrm{C}$ に融解し，エキクロディスク 13 (水系，ゲルマン社製）にて滤 過後血清試料とした.

\section{結 果 及び考 察}

\section{1. 励起 $(\mathbf{E x})$ 及び蛍光 $(\mathbf{E m})$ スペクトルの測定}

分析用移動相に括ける Yoh と PMBA の Ex 及び Em スペクトルを測定した。 Ex スペクトルは Yohが $270 \mathrm{~nm}$, PMBA が $255 \mathrm{~nm}, \mathrm{Em}$ スペクトルは Yoh が $360 \mathrm{~nm}, \mathrm{PMBA}$ が $345 \mathrm{~nm}$ にそれぞれ極大波長が見ら れたことから, 今回は Ex $280 \mathrm{~nm}, \operatorname{Em} 360 \mathrm{~nm}$ を用いた.

\section{HPLC 条件検討}

前処理用移動相に $0.05 \mathrm{M}$ リン酸塩緩衝液 ( $\mathrm{pH}$ 7.0) を用い分析用移動相のメタノールと0.1 M リン酸一カリウ ムの混液の比率をかえて分離を検討した，その結果，Yoh と PMBA の保持時間が血清中夾雑物と重ならず，分 離を満足するためにはメタノール $-0.1 \mathrm{M}$ リン酸一カリウム混液 $(40: 60, \mathrm{v} / \mathrm{v})$ が適当であった. この条件にて得 られたクロマトグラムをFig. 1 に示した. Yoh とPMBA の保持時間は，それぞれ平均で Yoh (19 分 30 秒), PMBA (26 分) で他の夾雑物より分離された.

\section{3. 検量線の作成}

横軸に Yoh 濃度を, 縦軸に PMBA に対する Yoh のピーク面積比をとり Yoh の検量線を作成した。 その 結果, 血清添加検量線が $2.5-15 \mathrm{ng} / \mathrm{ml}$ の範囲で回㷌式 $y=0.115 x+0.032, r=0.999$ で良好な直線性を示した. 血清 $100 \mu 1$ を用いた本法の検出限界は $0.8 \mathrm{ng} / \mathrm{ml}(\mathrm{S} / \mathrm{N}=3)$ であった. 再現性は変動係数で血清中濃度が，2.5， 5.0 及び $10 \mathrm{ng} / \mathrm{ml}$ のとき日内変動 $(n=5)$ は保持時間の C.V. が. $0.72-1.85 \%$, 面積比で $1.19-2.27 \%$, 日差変 動 $(n=10)$ 哚持時間の C.V.が $2.79-4.60 \%$, 面積比で $4.21-8.05 \%$ と良好であった (Table II). 
(A)

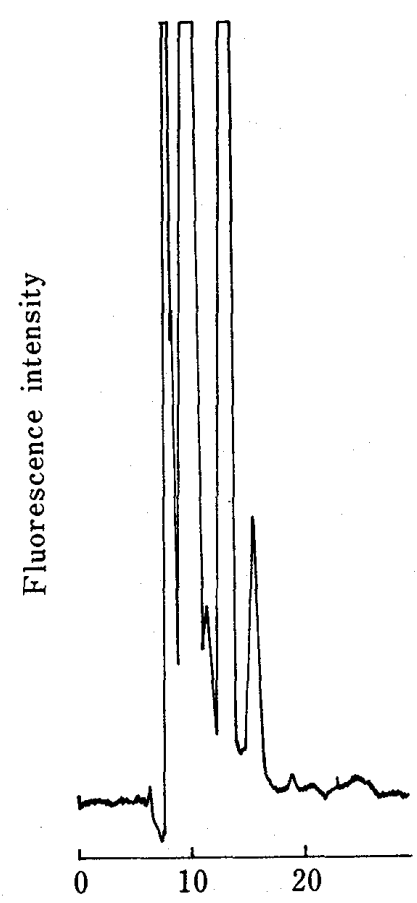

(B)

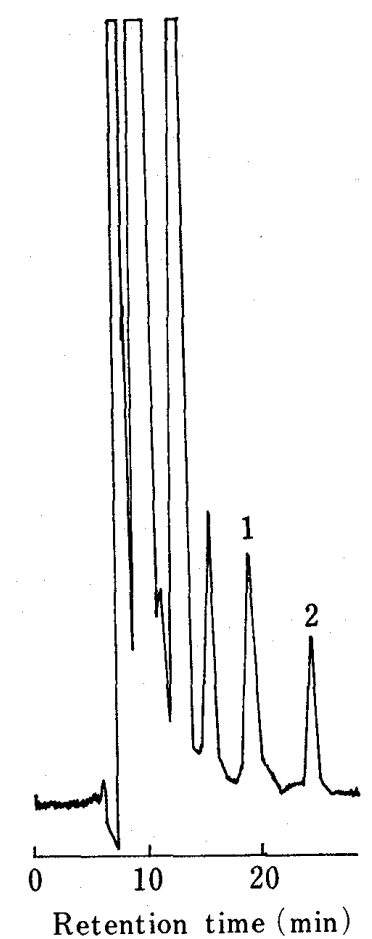

(C)

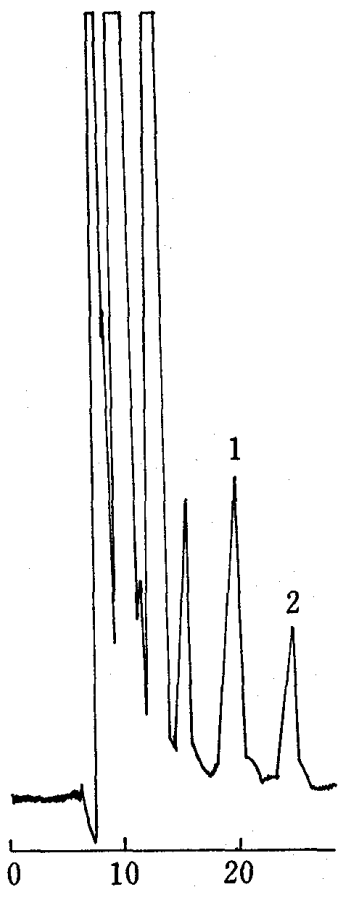

Fig. 1. The Chromatograms of Serum Containing Yoh

(A) blank serum, (B) 1 and 2 spiked in blank serum, (C) 2 spiked in serum after single oral administration of Yoh $(10 \mathrm{mg})$.

Peak: 1 , Yoh; 2, PMBA.

TABLE II. Reproducibility for Analyses of Yoh

\begin{tabular}{|c|c|c|c|c|}
\hline \multirow[t]{2}{*}{$\begin{array}{l}\text { Concentration of } \\
\text { Yoh } / \mathrm{ng} \cdot \mathrm{ml}^{-1}\end{array}$} & \multicolumn{2}{|c|}{$\begin{array}{l}\text { Within-run } \\
\text { C.V. \% } \\
(n=5)\end{array}$} & \multicolumn{2}{|c|}{$\begin{array}{c}\text { Day-to-day } \\
\text { C.V. \% } \\
(n=10)\end{array}$} \\
\hline & $\mathrm{RT}^{\alpha)}$ & $\mathbf{P A}^{b)}$ & $\mathrm{RT}^{a)}$ & $\mathbf{P A}^{b)}$ \\
\hline 2.5 & 1.85 & 1.72 & 4.60 & 8.05 \\
\hline 5.0 & 0.83 & 1.19 & 2.79 & 6.72 \\
\hline 10.0 & 0.72 & 2.27 & 4.51 & 4. 21 \\
\hline
\end{tabular}

a) Retention time, $b$ ) peak area ratio.

TABLE III. Recovery of Yoh Added to Blank Serum

\begin{tabular}{ccc}
\hline $\begin{array}{c}\text { Added } \\
(\mathrm{ng} / \mathrm{ml})\end{array}$ & $\begin{array}{c}\text { Found } \\
(\mathrm{ng} / \mathrm{ml})\end{array}$ & $\begin{array}{c}\text { Recovery } \\
(\%)\end{array}$ \\
\hline 2.5 & 2.76 & 110.4 \\
5.0 & 5.09 & 101.8 \\
10.0 & 9.93 & 99.3 \\
Mean \pm S.D. & & $103.8 \pm 5.8$ \\
\hline
\end{tabular}

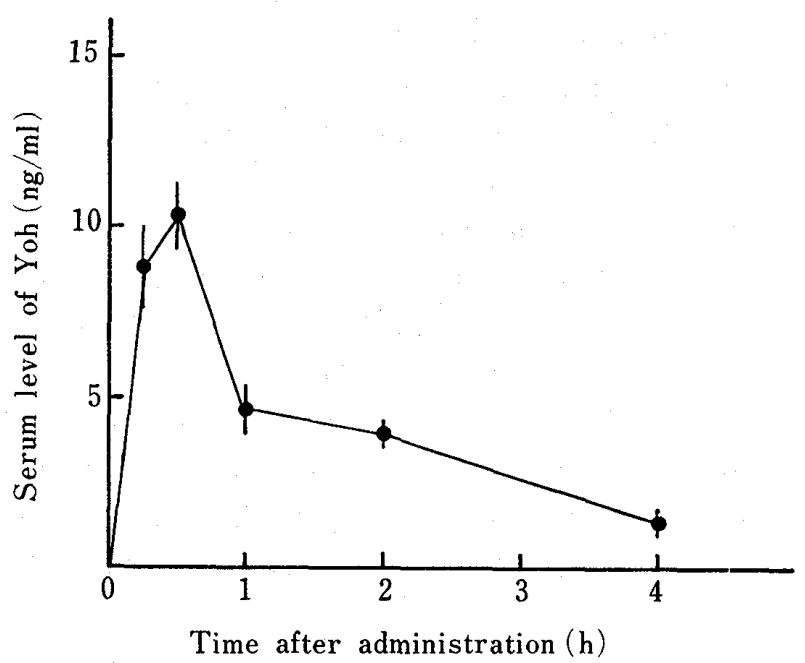

Fig. 2. Change in Serum Level of Yoh in Men Each point represents the mean \pm S.D. $(n=5)$.

\section{4. 添加回収実験}

ブランク血清（及び $0.05 \mathrm{M}$ リン酸塩緩衝液 $\mathrm{pH} 7.0) 1 \mathrm{ml}$ に Yoh $(2.5,5.0$ 及び $10 \mathrm{ng}$ ) と PMBA (1.5 $\mu \mathrm{g})$ を添加して本定量法にて測定したときの回収率は平均 $103.8 \%$ と良好な成績であった(Table III). 
TABLE IV. Pharmacokinetic Parameters of Yoh after Oral Administration of $10 \mathrm{mg}$

\begin{tabular}{cccccc}
\hline Subject & $\begin{array}{c}\text { Age } \\
(\text { years })\end{array}$ & $\begin{array}{c}\text { Weight } \\
(\mathrm{kg})\end{array}$ & $\begin{array}{c}A U C \\
\left(\mathrm{ng} \cdot \mathrm{h} \cdot \mathrm{ml}^{-1}\right)\end{array}$ & $\begin{array}{c}K_{\mathrm{el}} \\
(\mathrm{h})\end{array}$ & $\begin{array}{c}t_{1 / 2 \mathrm{el}} \\
(\mathrm{h})\end{array}$ \\
\hline $\mathrm{a}$ & 24 & 70 & 21.00 & 0.52 & 1.32 \\
$\mathrm{~b}$ & 23 & 65 & 20.20 & 0.53 & 1.30 \\
$\mathrm{c}$ & 22 & 61 & 19.10 & 0.55 & 1.25 \\
$\mathrm{~d}$ & 19 & 56 & 19.00 & 0.46 & 1.51 \\
$\mathrm{e}$ & 21 & 63 & 19.20 & 0.52 & 1.21 \\
Mean士S.D. & & & $19.70 \pm 0.87$ & $0.52 \pm 0.03$ & $1.32 \pm 0.12$ \\
\hline
\end{tabular}

\section{5. ヒト血清中 Yoh の濃度推移}

健常男子 5 名に HYoh $10 \mathrm{mg}$ を経口投与した際の血清中 Yoh 濃度を本法により測定した (Fig. 2). その結 果, 血清中 Yoh は投与後 30 分で最高濃度 $\left(C_{\max }\right), 10.3 \pm 0.88 \mathrm{ng} / \mathrm{ml}$ (平均值士標準偏差, $\left.n=5\right)$ に達し, その 後徐々に減少した。 また，薬物濃度・時間曲線下面積 $\left(A U C_{0-4}\right)$, 生体内半減期 $\left(t_{1 / 2 \in 1}\right)$ 及び生体内消失速度定数 $\left(K_{\mathrm{e} 1}\right)$ は Table IVに示すよらな結果となった。

結

論

今回著者らが検討した前好理装監つきHPLCを用いた本測定法は，1検体あたりの分析所要時間が 30 分以内 そ短く，操作も簡単で再現性の良い方法である。今後は，今回確立した HPLC 法を用い製剤中の Yoh とその他 の薬物との分析について検討する予定である.

\section{引用 文 献}

1) A. Morales, D. H. C. Surridge, P. G. Marshall, J. Fenemore, J. Urol., 128, 45 (1928).

2) J. T. Clark, E. R. Smith, J. M. Davidson, Physiol. Beha., 35, 517 (1985).

3) J. A. Owen, S. L. Nakatsu, J. Fenemore, M. Condra, D. H. C. Surridge, A. Morales, Eur. J. Clin. Pharmacol., 32, 577 (1987).

4) J. Buffun, J. Psychoact. Drugs., 17, 131 (1987).

5) K. Reid, A. Morales, C. Harris, D. H. C. Surridge, M. Condra, J. A. Owen, J. Fenemore, Lancet, 22, 421 (1987).

6) M. R. Goldberg, L. Speier, D. Robertson, J. Liq. Chromatogr., 7, 1003 (1984).

7) B. Drqet, L. Doare, G. Gaudel, J. Chromatogr., 311, 449 (1984).

8) J. A. Owen, S. L. Nakatsu, M. Condra, D. H. C. Surridge, J. Fenemore, A. Morales, J. Chromatogr., 342, 333 (1985).

9) O. Salama, F. Belal, Analyst., 111, 581 (1986).

10) 千葉良子, 石井耀子, 分析化学, 35, 323 (1986).

11) A. Akbari, A. D. Jenigan, P. B. Bush, N. H. Booth, J. Chromatogr., 361, 400 (1986).

12）千葉良子, 石井耀子, 分析化学, 印刷中. 